\begin{tabular}{r} 
- F I N A N S E I P R A W O F I N A N S O W E \\
\hline • Journal of Finance and Financial Law • \\
$\qquad \begin{array}{r}\text { https://doi.org/10.18778/2391-6478.1.1.02 } \\
\text { Maciej Górski } \\
\text { Mydziału Ekonomiczno-Socjologicznego, } \\
\text { kierunku Finanse i Rachunkowość }\end{array}$
\end{tabular}

\title{
ZASTOSOWANIE TEORII LOG-PERIODYCZNOŚCI W PROGNOZOWANIU KRACHÓW GIEŁDOWYCH
}

\begin{abstract}
Streszczenie
W niniejszym artykule zaprezentowane zostanie zastosowanie najnowszej metody prognozy wystąpienia krachów giełdowych w oparciu o analizę fraktalną. Zawarte w nim wnioski mają na celu wykazanie, że trajektorie cen akcji zawierają pewne wzorce log-periodyczne, które potwierdzają występowanie słabej hipotezy rynku efektywnego. Owe zjawiska mogą również wynikać ze specyficznych zachowań inwestorów. Teoria log-periodyczności może być zastosowana do prognozowania zmian trendów. W pracy zostanie zbadana skuteczność predykcji na jej podstawie w odniesieniu do skrajnie różnych (pod względem rozwoju) rynków akcji.

Słowa kluczowe: efektywność rynku kapitałowego, analiza techniczna, teoria log-periodyczności, krach giełdowy, analiza fraktalna.
\end{abstract}

\section{WPROWADZENIE}

Głównym celem poniższego artykułu jest weryfikacja prawdziwości słabej hipotezy rynku efektywnego w oparciu o metody analizy fraktalnej. Przedstawione w nim analizy będą opierać się na metodach statystycznych francuskiego ekonofizyka Didiera Sornette'a - jednego z twórców teorii log-periodyczności. Do zastosowania modelu log-periodycznego w prognozowaniu krachów giełdowych zostaną wykorzystane dane indeksów WIG oraz S\&P 500 z lat 2003-2008. Obliczenia przeprowadzono w programie Solver aplikacji Microsoft Excel 2007. Badane zostały następujące okresy: hossa w latach kwiecień 2004-wrzesień 2007 oraz krach giełdowy z października 2007 r. Istotność prognoz została sprawdzona za pomocą testów statystycznych.

W pracy zostaną poddane analizie następujące hipotezy:

1. Teoria log-periodyczności skutecznie prognozuje wystąpienie czasu rozpoczęcia krachu lub korekty (zmiany trendu) na skrajnie różnych pod względem wielkości kapitalizacji - rynkach giełdowych; 
2. Wprowadzenie oscylacji log-periodycznych statystycznie istotnie poprawia jakość modelu i dopasowanie danych teoretycznych do empirycznych dla historycznych wartości indeksów;

3. Zachowanie kursu głównego indeksu na relatywnie słabo rozwiniętym polskim rynku kapitałowym odpowiada najsłabszej formie teorii rynku efektywnego; natomiast typowe metody analizy technicznej, do których zalicza się także teoria log-periodyczności, nie są odpowiednie dla prognoz kursu najbardziej rozwiniętego indeksu amerykańskiego;

4. Precyzja prognoz czasu rozpoczęcia się zmiany trendu zależy ściśle od zastosowanej metody estymacji, w szczególności od rodzaju formuły log-periodyczności.

Głównym celem analizy jest weryfikacja wyżej wymienionych hipotez, w szczególności zbadanie, czy:

- przyczyny krachu giełdowego zapoczątkowanego we wrześniu/październiku 2007 r. można utożsamiać z działaniami spekulantów i specyficznym zachowaniem inwestorów,

- na wykresach wartości indeksów S\&P 500 i WIG widoczne są w pewnych przedziałach czasu w latach 2003-2007 oscylacje periodyczne, którym towarzyszy nieliniowy trend o charakterze wykładniczym,

- procedura obliczeniowa oparta na teorii log-periodyczności może być z powodzeniem zastosowana dla rynków giełdowych: amerykańskiego i polskiego oraz krachu z lat 2007-2008,

- mimo wielu założeń statystycznych w zastosowaniu teorii log-periodycznej - różne modele oparte na niej - prezentują podobne wyniki.

Jako, że teoria log-periodyczności jest jednym z narzędzi analizy technicznej, którą stosuje się do zagregowanych cen akcji (indeksów), jej efektywność prognostyczna powinna być lepsza dla mniej rozwiniętego rynku polskiego zgodnie z zaawansowaną teorią rynku efektywnego. Inne czynniki jednak, takie jak: charakter trendu poprzedzającego gwałtowny spadki na rynkach, obecność lokalnych minimów/maksimów oraz relacja ilości spekulantów do fundamentalistów mogą okazać się decydującymi dla wyników predykcji modeli log-periodycznych.

\section{LOG-PERIODYCZNOŚĆ NA RYNKACH KAPITAŁOWYCH}

Rynki akcji są systemami dynamicznymi, na których oddziałują dwie klasy inwestorów: spekulanci (zazwyczaj są to zwolennicy analizy technicznej) i fundamentaliści. Zachowanie tych pierwszych prowadzi do nieliniowych, często wykładniczych trajektorii cen, a działania praktyków analizy fundamentalnej przyczyniają się do pojawienia się fluktuacji log-periodycznych z odpowiednimi właściwościami skalującymi. Zmiany cen danego aktywa są uzależnione od 
relacji popyt-podaż, inaczej mówiąc od różnicy pomiędzy zleceniami kupna i zleceniami sprzedaży $(\Delta)$.Wielkość zleceń netto $(\Delta)$ jest uzależniona od działań wszystkich traderów i zmienia się niemal natychmiastowo, odzwierciedlając przepływ informacji i opinie oraz nastroje inwestorów. Skrajne wartości $\Delta$ wpływają na trwałe odchylenia cenowe (np. wykazane jako logarytm ceny waloru) i są uzależnione od pewnych stałych czynników. Czynniki te powiązane są z zachowaniami uczestników rynku i są to: podążanie za trendem i preferowanie oszacowanej wartości fundamentalnej [Sornette 2003: 217-218].

Pierwsza strategia implikuje tezę, że inwestorzy reagują bardziej niż proporcjonalnie na duże zmiany cen, a ignorują małe skoki cenowe. Wielkość zleceń netto jest w tym przypadku równa różnicy logarytmu ceny dziś i wczoraj podniesionej do potęgi liczby większej od jedności. Prowadzi to do zjawiska punktu krytycznego (przemiany) czyli punktu, od którego następuje gwałtowna i stała zmiana trendu [Sornette 2003: 218].

W przypadku inwestorów fundamentalnych wielkość zleceń netto $(\Delta)$ występuje jako funkcja różnicy pomiędzy logarytmem ceny a logarytmem oszacowanej wartości rynkowej. W estymacji tej ostatniej często czyni się upraszczające założenia (np. dotyczące wskaźnika wzrostu dywidend), które poddają w wątpliwość jej precyzję odzwierciedlenia rzeczywistości. W konsekwencji trader wzorujący się na wartości fundamentalnej nie będzie dostrzegał bodźca do kupna walorów, gdy ta wartość nie różni się zbytnio od ceny rynkowej. Kierowanie się oszacowaną wartością rynkową odzwierciedlone jest w oscylacjach, których częstotliwość uzależniona jest od amplitudy odchyleń tej wartości od ceny rynkowej. Wspólne działanie obu grup (analityków technicznych, jak i fundamentalnych) na rynku prowadzi do coraz to częstszych oscylacji z ostrzejszymi wierzchołkami oraz coraz większej dynamiki trendu, zbiegających się w czasie krytycznym $\left(t_{c}\right)$. Z geometrycznego punktu widzenia, trajektorie cen $\mathrm{z}$ tymi dwiema charakterystykami przypominają spiralę, odzwierciedlającą hierarchiczną organizację zależności cena-dynamika w czasie - występują oscylacje log-periodyczne [Ide i Sornette 2002: 3-36].

Punkt krytyczny, który jest niejako odpowiednikiem rozpoczęcia krachu i charakteryzuje się występowaniem przed jego zaistnieniem oscylacji log-periodycznych, należy analizować przez pryzmat części składowych funkcji log-periodycznej. Mając na uwadze zmodyfikowaną postać równania [Oświęcimska $\mathrm{i}$ in. 2009: 1-2]:

$$
F(\lambda x)=\mu F(x)
$$

można uznać, że stała $\mu$ opisuje właściwości zmian systemu pod wpływem współczynnika skalującego $\lambda$. Zgodnie z teorią dyskretnego równania skalowania system wykazuje cechy samo-podobieństwa, gdy istnieje określona liczba parametrów $\lambda$ [Dróżdż, Bartolozzi i in. 2008]. 
Dążąc do wyznaczenia kompletnej formuły log-periodyczności należy najpierw przeanalizować koncept, który jest powiązany z występowaniem punktów krytycznych, czyli wykładniczy charakter zmian cen. Można go określić następującym równaniem [Dróżdż i in. 2008]:

$$
\log [p(t)]=A+B\left(t_{c}-t\right)^{\alpha}
$$

(formuła 1)

Powyższa równość wymaga pewnych objaśnień [Sornette 2003: 336-338]:

- nieznanymi argumentami są $A, B, t_{c}, \alpha$ i na podstawie powyższych danych wartości $t$ oraz zmiennej objaśnianej: $\log [p(t)]$ istnieje możliwość ich oszacowania,

- wartość $\alpha$ powinna oscylować, według twórcy koncepcji log-periodyczności - D. Sournetta - pomiędzy 0,2 i 0,8 . Z tego też powodu, aby funkcja odzwierciedlała trend rosnący (malejący) - parametr $B$ musi być ujemny (dodatni).

Wcześniej wymieniona funkcja periodyczna nie wymagała przyjęcia żadnych ustalonych zasad jej kształtowania i dlatego różni autorzy chcieli wyznaczyć jej najlepszą postać funkcyjną, możliwą do zastosowania w praktyce. W jej poszukiwaniu bardzo pomocnym elementem okazało się współwystępowanie powtarzających się, podobnych do siebie wzorców. Struktury te niosą za sobą najwięcej informacji o dynamice rynku. W końcowym rozrachunku otrzymano funkcję periodyczną w postaci szeregu Fouriera pozwalającą rozłożyć funkcję okresową na sumę funkcji trygonometrycznych.

$\mathrm{W}$ połączeniu z wcześniej omawianym równaniem wykładniczym - podstawowa formuła uwzględniająca log-periodyczne oscylacje prezentuje się następująco:

$$
\log [p(t)]=A+B\left(t_{c}-t\right)^{\alpha}\left\{1+C \cos \left[\omega \log \left(t_{c}-t\right)+\phi\right]\right\} \quad \text { (formuła 2) }
$$

gdzie $\omega$ związane jest z częstotliwością i równa się $\omega=2 \pi / \ln (\pi)$, natomiast parametr $\phi$ określa czas występowania oscylacji $(T)$. Interpretuje się go jako $\phi=-\omega \ln T$ [Dróżdż i in. 2008: 2-3]. Dla krótszych szeregów czasowych należy zastosować moduł funkcji kosinus, przez co model lepiej uwzględnia lokalne minima [Dróżdż i in. 2005: 2]. Warto zaznaczyć, że parametry $A, B, C$ zależą liniowo od czterech zmiennych: $t_{c}, \alpha, \phi$ oraz $\omega$. Najlepszym sposobem ich wyznaczenia jest nieliniowa metoda najmniejszych kwadratów lub zastosowanie innych algorytmów wyznaczania maksimów/minimów i parametrów równania (np. algorytm Levenberga-Marqardta). Warto wspomnieć, że wartość $t_{c}$ musi być większa od ostatniej daty próby, tak aby model mógł zostać wykorzystany do prognoz [Sornette i Johansen 2001]. 
Didier Sornette przedstawił jeszcze jedną postać funkcji log-periodycznej, zawierającą dwa dodatkowe parametry $\Delta_{t} \operatorname{oraz} \Delta_{\omega}$ :

$$
\begin{aligned}
& \log [p(t)]=A+B \frac{\left(t_{c}-t\right)^{\alpha}}{\sqrt{1+\left(\frac{t_{c}-t}{\Delta_{t}}\right)^{2 \alpha}}}\left\{1+C \cos \left[\omega \log \left(t_{c}-t\right)+\right.\right. \\
& \left.\left.+\frac{\Delta_{\omega}}{2 \alpha} \log \left(1+\left(\frac{t_{c}-t}{\Delta_{t}}\right)^{2 \alpha}+\Phi_{2}\right)\right]\right\}
\end{aligned}
$$

(formuła 3)

Powyższy wzór winien być stosowany dla dłuższych szeregów czasowych, ponieważ uwzględnia on płynne przejścia głównych trendów np. z malejącego na rosnący bez wystąpienia zjawiska krytycznego, czyli bez formowania się bańki spekulacyjnej [Sornette i Johansen 2001: 336].

Sornette i Zhou zbudowali również formułę log-periodyczną uwzględniającą harmoniczność funkcji log-periodycznej dla częstotliwości $2 \omega$, której postać wygląda następująco [Sornette i Zhou 2002: 1-3]:

$$
\begin{aligned}
& \log [p(t)]=A+B\left(t_{c}-t\right)^{\alpha}\left\{1+C \cos \left[\omega \log \left(t_{c}-t\right)+\phi_{1}\right]+\right. \\
& +D\left(t_{c}-t\right)^{\alpha} \cos \left[2 \omega \ln \left(t_{c}-t\right)+\phi_{2}\right]
\end{aligned}
$$

Powyższe równanie różni się od poprzednich dodaniem proporcjonalnej amplitudy $D$ i parametru $\phi_{2}$.

Parametry dotychczas wymienionych równań mają jedną poważną wadę. Objawia się ona w niestabilności parametrów z wyjątkiem parametru $\omega$ powiązanego z $\lambda$. Pozostałe z nich, zwłaszcza parametr $\alpha$, są nietrwałe ze względu na występowanie obserwacji „odstających” oraz zmiany długości próby. Problem braku uniwersalności parametru $\alpha$ został rozwiązany przez belgijskiego badacza N. Vandewalle'a, który zaproponował następującą postać modelu log-periodycznego [Vandewalle i in. 1999]:

$$
\log [p(t)]=A+B \ln \frac{t_{c}-t}{t_{c}}\left\{1+C \cos \left[\omega \log \left(\frac{t_{c}-t}{t_{c}}\right)+\phi\right]\right\} \quad \text { (formuła 5) }
$$

W powyższym równaniu założono, że parametr $\alpha$ powinien być zastąpiony przez logarytm naturalny. Oznacza to, że jego wartość jest bliska zeru. Dzięki temu zabiegowi ilość parametrów, którą należy wyznaczyć, zmniejszyła się o jeden element [Vandewalle $\mathrm{i}$ in. 1998]. 
Oczywiście błędnym jest założenie, że każda zauważalna fluktuacja na wykresie wartości indeksów czy nawet kursów akcji może być zaklasyfikowana jako pewien urywek rozkładu log-periodycznego. Kilka z tych fluktuacji bowiem jest spowodowana czynnikami zewnętrznymi, które występują całkowicie losowo w przeciwieństwie do hierarchicznych, wywołanych zachowaniami inwestorów - oscylacji. Dzięki schematycznym postaciom tych ostatnich możliwe było wyznaczenie ich postaci funkcyjnej oraz udowodnienie stabilności parametru $\lambda$ [Dróżdż, Ruf i in. 2008].

\section{ZAKRES I CEL BADANIA}

Przeprowadzone badanie empiryczne, wykorzystujące formuły log-periodyczności w predykcji krachu opiera się na wykresie wartości dwóch indeksów: amerykańskiego S\&P 500 i polskiego WIG-u. Oba indeksy w swoich krajach obejmują największą wartość kapitalizacji spółek giełdowych. Dane obejmują okres: 2003-2010 i pochodzą z portalu: www.stooq.pl. Obliczenia zostały przeprowadzone w aplikacji Microsoft Excel, w której do optymalizacji parametrów posłużono się programem Solver.

Efektem końcowym badania jest oszacowany na podstawie danych historycznych czas krytyczny tj. moment, w którym powinien rozpocząc się krach giełdowy. Podkreśla się, że teoria log-periodyczności powinna przede wszystkim wskazywać dzień zapoczątkowania zmiany trendu. Jej celem nie jest wyznaczenie dokładnej wartości indeksu w punkcie szczytowym. Oszacowaną wartość $T_{c}$ można porównać do rzeczywistej wartości czasu krytycznego i w ten sposób ocenić zdolność prognostyczną modelu opartego na danej formule log-periodyczności (prognoza ex post).

Wybrane indeksy reprezentują dwa skrajnie różne rynki: należący do grupy emerging markets rynek giełdowy w Polsce (WIG) oraz najbardziej rozwinięty na świecie - rynek amerykański (S\&P 500). Wysuwa się tezę, że oba indeksy reprezentują różne formy efektywności rynku. Rynek polski utożsamia się $\mathrm{z}$ formą najsłabszą, gdzie fundamenty spółki i wiadomości inside traderów w głównej mierze determinują ceny akcji, lecz stosowanie analizy technicznej również może okazać się skuteczne. Rynek amerykański natomiast odzwierciedla formę półmocną, a niekiedy najmocniejszą. $Z$ tego powodu można założyć, że zastosowanie teorii log-periodyczności, opartej na ruchach historycznych - osiągnie lepsze rezultaty dla rynku polskiego. Autor zbada tę tezę i spróbuje udowodnić, że teoria log-periodyczności skutecznie prognozuje wystąpienie typowo spekulacyjnego krachu giełdowego na wybranych, skrajnie różnych rynkach.

Powyższe daty zostały wybrane na podstawie:

- formacji najwyższego szczytu utworzonego w danym czasie i nie następującymi po nim kolejnymi, wyższymi maksimami, 
- zjawiska tak zwanej „super-bańki”, gdzie po odreagowaniu na pewny gwałtowniejszy spadek - następuje kolejny lokalny szczyt, po którym rozpoczyna się dopiero trwały trend malejący.

Tabela 1. Czas występowania zmian trendów zaobserwowanych na indeksie WIG i S\&P 500

\begin{tabular}{|l|c|}
\hline \multicolumn{2}{|c|}{ WIG } \\
\hline Oficjalna data rozpoczęcia krachu & 15 października 2007 r. \\
\hline Skonwertowana data & 7,792 \\
\hline \multicolumn{2}{|c|}{ S\&P 500 } \\
\hline Oficjalna data rozpoczęcia krachu & 12 października 2007 r. \\
\hline Skonwertowana data & 7,784 \\
\hline
\end{tabular}

Źródło: opracowanie własne na podstawie: Sornette [2003].

Przed przystąpieniem do prezentacji wyników prognozy pierwszego krachu giełdowego z 2007 r. przy zastosowaniu modelu log-periodycznego dla indeksów: WIG i S\&P 500, warto wyjaśnić, w jaki sposób dokonano obliczeń. Wykorzystano 4 główne, wcześniej opisane formuły log-periodyczne: podstawową formułę Sornette'a (oznaczoną jako formułę 2), formułę uwzględniającą przejścia trendów (formuła 3), formułę harmoniczną (formuła 4), wzór Vandewalle’a (formuła 5).

Formuła 1 nie zawiera części funkcji odpowiedzialnej za oscylacje, dlatego w analizie empirycznej została ona pominięta. W celu dopasowania danych empirycznych do przeprowadzenia estymacji należało usunąć wszystkie dni, w których nie odbywały się sesje giełdowe, co skróciło próbę. Czas został odpowiednio skonwertowany.

W programie Solver zastosowano jako funkcję celu - kryterium minimalizacji kwadratów reszt pomiędzy rzeczywistymi wartościami (kursu) indeksu podanych $\mathrm{w}$ logarytmie a wartościami wyznaczonymi $\mathrm{z}$ funkcji log-periodycznej. Od minimalizacji kwadratów reszt zależą wartości parametrów funkcji, które Solver dopasowuje do funkcji kryterium (metoda najmniejszych kwadratów).

W podstawowej formule Sornette'a należy oszacować 7 nieznanych parametrów: $A, B, C, \alpha, \omega, \varphi$ oraz najważniejsze $T_{c}$. Wybrano osiem charakterystycznych $t_{\text {start }}$, w okolicach których następowały widoczne maksima/minima lub inne zdarzenia o charakterze technicznym: 01.01.2003 r., 01.01.2004 r., 01.10.2004 r., 28.02.2005 r., 01.06.2005 r., 01.10.2005 r., 01.02.2006 r., 01.07.2006 r.

Następnie dla tych dat startowych zastosowano identyczne $t_{\text {last }}(30.06 .2007 \mathrm{r}$.), biorąc pod uwagę wcześniej określone kryteria. Po przeprowadzeniu estymacji, kierując się najlepszymi oszacowaniami $T_{c}$, tzn. takimi, które najbardziej były 
zbliżone do prawdziwej daty wystąpienia pierwszej kryzysowej korekty na WIG lub S\&P500, dokonano wyboru dwóch $t_{\text {start }}$, prezentujących najlepsze wyniki. W wybranych datach startowych przeprowadzono estymacje dla 5-10 wielkości $t_{\text {last }}$, aby zbadać niezmienniczość wcześniej wyznaczonych wyników parametrów, zwłaszcza czasu krytycznego.

Warto dodać, że przed przeprowadzeniem estymacji dokonano restrykcji na 3 parametry w modelu. Zgodnie ze wskazówkami innych autorów parametr $\alpha$ powinien oscylować pomiędzy wartościami 0,2 i 0,8 . Została podtrzymana restrykcja na parametr $\lambda=2$ [Dróżdż, Ruf i in. 2008], od którego wartości zależy wartość $\omega$, a wartość $T_{c}$ powinna być większa od $t_{\text {last }}$, aby prognoza była logiczna.

\section{WYNIKI BADANIA}

Wyniki analiz przedstawiają się dość obiecująco. Dla około 5-6 $t_{\text {start }} \mathrm{z}$ ustalonym $t_{\text {last }}=31.06 .2007 \mathrm{r}$. dla obu analizowanych indeksów, $T_{c}$ oscylowało $\mathrm{w}$ okolicach daty krytycznej (+/- miesiąc), za którą uznano dla indeksu S\&P 500 przedział czasowy 12.10.2007 r.-19.10.2007 r. (skonwertowane: $t=7,784-7,803$ ), natomiast dla indeksu WIG - przedział czasowy 15.10.2007 r.-22.10.2007 r. $(t=7,792-7,811)$. W przedziałach tych nastąpiły pierwsze wyraźne spadki kursów indeksów i zostały one poprzedzone maksimami indeksów, które już nie zostały ponownie osiągnięte. Poniżej znajdują się wyniki estymacji $T_{c}$ i kwadraty błędów reszt dla różnych dat końcowych, dla $t_{\text {start }}=$ luty 2005 r. dla indeksu WIG oraz $t_{\text {start }}=$ październik 2005 r. dla S\&P 500.

Tabela 2. Wyniki estymacji parametru $T_{c}$ oraz wartości sumy kwadratów reszt dla WIG-u dla danych dat końcowych (data startowa $=28.02 .2005$ r.)

\begin{tabular}{|l|c|c|}
\hline \multicolumn{1}{|c|}{ Data ostateczna estymacji } & $\begin{array}{c}\text { Estymowany czas krytyczny } \\
\text { (rzeczywisty: } 7,792-7,811)\end{array}$ & $\begin{array}{c}\text { Suma kwadratów błędów } \\
\text { reszt modelu }\end{array}$ \\
\hline Czerwiec 2006 & 9,134 & 0,5088 \\
\hline Grudzień 2006 & 7,861 & 0,6549 \\
\hline Luty 2007 & 7,868 & 0,6899 \\
\hline Marzec 2007 & 7,833 & 0,0716 \\
\hline Kwiecień 2007 & 7,776 & 0,7326 \\
\hline Maj 2007 & 7,777 & 0,7370 \\
\hline Czerwiec 2007 & 7,824 & 0,7576 \\
\hline Lipiec 2007 & 7,859 & 0,7794 \\
\hline Sierpień 2007 & 7,935 & 1,1095 \\
\hline
\end{tabular}

Źródło: jak do tab. 1. 
14 Maciej Górski, Zastosowanie teorii log-periodyczności w prognozowaniu...

Tabela 3. Wyniki estymacji parametru $T_{c}$ oraz wartości sumy kwadratów reszt dla S\&P 500 dla danych dat końcowych (data startowa $=03.10 .2005$ r.

\begin{tabular}{|l|c|c|}
\hline $\begin{array}{c}\text { Data ostateczna } \\
\text { estymacji }\end{array}$ & $\begin{array}{c}\text { Estymowany czas krytyczny } \\
\text { (rzeczywisty: 7,784-7,803) }\end{array}$ & $\begin{array}{c}\text { Suma kwadratów błędów } \\
\text { reszt modelu }\end{array}$ \\
\hline Czerwiec 2006 & 6,583 & 0,0765 \\
\hline Wrzesień 2006 & 7,620 & 0,0381 \\
\hline Grudzień 2006 & 7,728 & 0,0417 \\
\hline Luty 2007 & 7,887 & 0,0522 \\
\hline Kwiecién 2007 & 7,838 & 0,0596 \\
\hline Czerwiec 2007 & 7,832 & 0,0622 \\
\hline Sierpién 2007 & 7,940 & 0,1657 \\
\hline
\end{tabular}

Źródło: jak do tab. 1.

Tabela 4. Wyniki estymacji parametru $T_{c}$ dla drugich optymalnych dat startowych (dla WIG $t_{\text {start }}=$ październik 2004 r., a dla S\&P $500 t_{\text {start }}=$ październik 2004 r.) przy wybranych datach końcowych

\begin{tabular}{|l|c|c|}
\hline $\begin{array}{c}\text { Data ostateczna } \\
\text { estymacji }\end{array}$ & $\begin{array}{c}\text { Estymowany czas krytyczny } \\
\text { (rzeczywisty: 7,792-7,811) dla WIG }\end{array}$ & $\begin{array}{c}\text { Estymowany czas krytyczny } \\
\text { (rzeczywisty: 7,784-7,803) dla S\&P 500 }\end{array}$ \\
\hline Grudzień 2006 & 7,863 & 7,701 \\
\hline Luty 2007 & 7,870 & 7,785 \\
\hline Marzec 2007 & 7,842 & 7,799 \\
\hline Kwiecień 2007 & 7,787 & 7,792 \\
\hline Czerwiec 2007 & 7,829 & 7,795 \\
\hline
\end{tabular}

Źródło: jak do tab. 1.

Tabela 5. Wyniki estymacji $T_{c}$ dla określonej daty końcowej = czerwiec $2007 \mathrm{r}$. i wszystkich $t_{\text {start }}$ dla obu indeksów (wybrane optymalne daty startowe zostały wyeksponowane pogrubioną czcionką)

\begin{tabular}{|l|c|c|}
\hline $\begin{array}{c}\text { Daty rozpoczęcia } \\
\text { estymacji }\end{array}$ & $\begin{array}{c}\text { Estymowany czas krytyczny } \\
\text { (rzeczywisty: 7,792-7,811) dla WIG }\end{array}$ & $\begin{array}{c}\text { Estymowany czas krytyczny } \\
\text { (rzeczywisty: 7,784-7,803) dla S\&P 500 }\end{array}$ \\
\hline Styczeń 2003 & 7,929 & 7,823 \\
\hline Styczeń 2004 & 7,973 & 8,010 \\
\hline Październik 2004 & $\mathbf{7 , 8 2 9}$ & $\mathbf{7 , 7 9 5}$ \\
\hline Luty 2005 & $\mathbf{7 , 8 2 4}$ & 7,791 \\
\hline Czerwiec 2005 & 7,802 & 7,828 \\
\hline Październik 2005 & 7,701 & $\mathbf{7 , 8 3 2}$ \\
\hline Luty 2006 & 7,770 & 7,625 \\
\hline Lipiec 2006 & 7,741 & 7,847 \\
\hline
\end{tabular}

Źródło: jak do tab. 1. 
Mając na uwadze wartości w wymienionych tabelach można wyciągnąć następujące wnioski:

- zdecydowana większość oszacowanych dat krytycznych dla danych $t_{\text {last }}$ na obu rynkach odzwierciedla czas wystąpienia kryzysu zbliżony do rzeczywistego przedziału (zazwyczaj występują mało znaczące zawyżenia),

- szacowanie parametrów funkcji log-periodycznej dla przedziału czasowego kończącego się około miesiąc (i mniej) przed kryzysem może zawyżać wartość $T_{c}$; dla $t_{\text {last }}$ powyżej 1,25 roku przed wystąpieniem sytuacji kryzysowej otrzymano mało wiarygodne wyniki, ze względu na zbyt duże skrócenie próby i pominięcie najważniejszych informacji w końcowych miesiącach trendu rosnącego,

- optymalnie jest szacować parametry dla przedziału czasowego kończącego się od 2 do 10 miesięcy (w skrajnych przypadkach nawet roku); potwierdzają to wyniki dla drugich optymalnych $t_{\text {start }}$ na obu rynkach,

- zgodne prognozy pozwalają przypuszczać, że trend rosnący miał charakter spekulacyjny na obu rynkach, co spowodowało powstanie punktu krytycznego (pęknięcie bańki), w którym zbiegały się oscylacje; choć geneza kryzysu finansowego z 2007 r. ma podstawy makroekonomiczne, zmiany kursów indeksów były spowodowane głównie zachowaniem stadnym inwestorów.

Pozostałe formuły log-periodyczne zostały zastosowane tylko dla jednej daty startowej. Sprawdzono dla niej spójność wyników danych metod dla różnych $t_{\text {last }}$, wykorzystując wszystkie trzy pozostałe formuły.

Tabela 6. Wyniki prognoz czasu krytycznego dla określonego, optymalnego $t_{\text {start }}$ (dla WIG $t_{\text {start }}=$ październik 2004 r., a dla S\&P $500 t_{\text {start }}=$ październik 2004 r.) przy wykorzystaniu trzech pozostałych formuł

\begin{tabular}{|c|c|c|c|}
\hline Formuły & $\begin{array}{c}\text { Daty końcowe } \\
\left(t_{\text {last }}\right)\end{array}$ & $\begin{array}{c}\text { Czas krytyczny WIG } \\
\text { (rzeczywisty: } 7,792-7,811 \text { ) }\end{array}$ & $\begin{array}{l}\text { Czas krytyczny S\&P 500 } \\
\text { (rzeczywisty: } 7,784-7,803 \text { ) }\end{array}$ \\
\hline \multirow{4}{*}{$\begin{array}{l}\text { Formuła } 3 \text { - } \\
\text { uwzględniająca } \\
\text { przejście tren- } \\
\text { du }\end{array}$} & Grudzień 2006 & 7,815 & 7,706 \\
\hline & Marzec 2007 & 7,845 & 7,801 \\
\hline & Kwiecień 2007 & 7,791 & 7,795 \\
\hline & Czerwiec 2007 & 7,829 & 7,795 \\
\hline \multirow{4}{*}{$\begin{array}{l}\text { Formuła } 4 \text { - } \\
\text { harmoniczna }\end{array}$} & Grudzień 2006 & 7,789 & 7,693 \\
\hline & Marzec 2007 & 7,774 & 7,803 \\
\hline & Kwiecień 2007 & 7,762 & 7,797 \\
\hline & Czerwiec 2007 & 7,821 & 7,796 \\
\hline \multirow{4}{*}{$\begin{array}{l}\text { Formuła } 5 \text { - } \\
\text { Vandewalle'a }\end{array}$} & Grudzień 2006 & 8,219 & 7,730 \\
\hline & Marzec 2007 & 7,890 & 7,847 \\
\hline & Kwiecień 2007 & 7,943 & 7,836 \\
\hline & Czerwiec 2007 & 7,852 & 7,813 \\
\hline
\end{tabular}

Źródło: jak do tab. 1. 
Zaobserwowano, że:

- wszystkie formuły log-periodyczności prezentują zbliżone, spójne wyniki,

- rzeczywisty czas rozpoczęcia kryzysu pokrywa się w większości przypadków z prognozą.

W celu sprawdzenia statystycznej istotności części periodycznej w podstawowej formule log-periodycznej - zastosowano test Wilka. W tym celu posłużono się następującym zestawem hipotez:

$\mathrm{H}_{1}: C=0$, czyli część log-periodyczna funkcji nie poprawia istotnie jakości modelu,

$\mathrm{H}_{2}: C \neq 0$, główne parametry pełnej formuły log-periodycznej są statystycznie istotne.

Tabela 7 prezentuje wyniki dla optymalnych $t_{\text {start }}$ i $t_{\text {last }}$.

Tabela 7. Wyniki testu Wilka dla optymalnych wartości $t_{\text {start }} \mathrm{i} t_{\text {last }}$ indeksów WIG i S\&P 500

\begin{tabular}{|c|c|c|c|c|c|c|}
\hline Indeks, $t_{\text {start }}, t_{\text {last }}$ & $\sigma_{1}$ & $\sigma_{2}$ & $L_{1}$ & $L_{2}$ & $T_{1,2}$ & $P_{1,2}(\%)$ \\
\hline WIG 02.2005-06.2007 & 0,001925 & 0,001293 & 1000,61 & 1117,18 & 233,15 & $<10^{-4}$ \\
\hline WIG 10.2004-06.2007 & 0,001955 & 0,001176 & 1172,75 & 1347,93 & 350,34 & $<10^{-4}$ \\
\hline S\&P 500 10.2005-06.2007 & 0,00052 & 0,000142 & 1033,153 & 1318,7423 & 571,1786 & $<10^{-4}$ \\
\hline S\&P 500 10.2004-06.2007 & 0,000476 & 0,00038 & 1662,49 & 1739,156 & 153,332 & $<10^{-4}$ \\
\hline
\end{tabular}

Źródło: opracowanie własne na podstawie Sornette i Zhou [2002: 10-11].

Wysokie statystyki $T_{1,2}$ powodują, że prawdopodobieństwo popełnienia błędu I rodzaju, czyli odrzucenia hipotezy pierwszej na korzyść drugiej, gdy ta pierwsza jest prawdziwa, jest bardzo niskie. $Z$ tego powodu, we wszystkich przypadkach należy odrzucić hipotezę $\mathrm{H}_{1}$ na korzyść $\mathrm{H}_{2}$ - dodanie części logperiodycznej widocznie poprawia jakość wyników i zdolności prognostyczne, zwłaszcza oszacowanie parametru $T_{c}$. W teście zastosowano rozkład chi-kwadrat o 1 stopniu swobody. Zbadano również, czy dodanie parametru $D$ w formule harmonicznej istotnie poprawia jakość prognostyczną modelu. We wszystkich przypadkach hipoteza podstawowa nie została odrzucona. Sugerowałoby to, że główna formuła Sornette'a lepiej tłumaczy zachowanie się kursów indeksów amerykańskiego i polskiego w latach przed kryzysem giełdowym w 2007 r. niż bardziej rozbudowana formuła harmoniczna.

\section{PODSUMOWANIE}

Specyfika natury ludzkiej, w tym inwestorów, ich zdolność do naśladownictwa, zachowań stadnych, tworzenia hierarchii informacyjnych, w połączeniu z działaniami ,fundamentalistów” prowadzi do typowo nieliniowych zależności 
kształtowania się trajektorii wartości indeksów giełdowych, „ozdobionych” powtarzającymi się oscylacjami. Owe cechy kształtowania się cen rynku zawierają pewne informacje dotyczące przyszłego krachu.

Twarde dowody występowania log-periodyczności w algebrze, biologii, analizie fraktalnej i innych naukach pozwoliło twórcy tej koncepcji - D. Sornette'owi - zastosować tę teorię dla rynków finansowych. Jak pokazano w artykule - może być ona śmiało wykorzystana do prognozowania anomalii rynkowych. Istnieje jednak szereg ograniczeń i założeń w tworzeniu prognoz na niej opartych. Przede wszystkim metoda log-periodyczna, jak pokazują badania empiryczne, z dużą dokładnością dopasowuje się do danych empirycznych tylko w przypadku typowo spekulacyjnych ruchów indeksów. Należy również zwrócić uwagę, że modele log-periodyczne mają skłonności do tworzenia tzw. ,zagnieżdżeń", wynikających ze specyfiki funkcji Weiestrasse'a oraz cech samopodobieństwa.

Mimo powyższych ograniczeń, teoria log-periodyczna jest bardzo dobrym predyktorem załamania rynkowego z 2007 r. Należy jeszcze raz zaznaczyć, że estymacja nie wyznaczała dokładnej wartości indeksu w punkcie krytycznym. Jest to pewna wada modelu, lecz można ją pominąć, gdyż tak naprawdę celem jego stosowania jest prognoza czasu rozpoczęcia zmiany trendu, która okazała się trafna. Wszystkie wykorzystane formuły prezentowały spójne wyniki, a część periodyczna istotnie poprawiła wartość współczynnika determinacji w obu przypadkach. Zastosowanie różnych wartości $t_{\text {start }}$ i $t_{\text {last }}$ pozwoliło zbadać wrażliwość parametrów oraz wybranie modelu optymalnego, ze względu na minimalizację kwadratów reszt. Test Wilka we wszystkich przypadkach potwierdził tezę, że zastosowanie modelu z oscylacjami log-periodycznymi istotnie poprawia dopasowanie danych empirycznych do teoretycznych dla wszystkich indeksów.

Sukcesy większości prognoz dla indeksu WIG wynikają z charakteru polskiego rynku giełdowego. Jest on nadal rynkiem rozwijającym się, o relatywnie niskiej wielkości obrotów, przez co częściej jest narażony na ataki spekulantów. Z kolei, dla rynku amerykańskiego stosowanie analizy technicznej do predykcji krachów okazuje się niewłaściwym krokiem, ale tylko w krótkiej perspektywie. Na rynku tym załamania indeksu S\&P 500 są wynikiem trwających latami mechanizmów endogenicznych, napędzanych czynnikami zewnętrznymi, typu: niewypłacalność banków sprzedających CDS-y.

Zaprezentowane $\mathrm{w}$ artykule analizy, mogą być ulepszone przy wykorzystaniu bardziej zaawansowanych metod estymacji aniżeli metoda Newtona, dzięki którym można uzyskać dokładniejsze wyniki czasu krytycznego. Postuluje się tutaj stosowanie nieliniowej metody najmniejszych kwadratów czy też algorytmu Levenberga-Marquardta. Praca może być również poszerzona o analizę ,anty-bańki" z lat 2007-2009, korekty z lipca 2011 r. i prognozę ex ante długoterminową dla innych indeksów oraz rynku surowcowego. 
Znalezione $\mathrm{w}$ pracy uporządkowane, hierarchiczne oscylacje periodyczne, występujące w kursach historycznych indeksów S\&P 500 oraz WIG, spójność większości wyników oraz małe błędy oszacowań - potwierdza aktualność i prawdziwość słabej hipotezy rynku efektywnego. Pomimo tego, że rynki kapitałowe są coraz bardziej rozwinięte, zastosowanie analizy technicznej wciąż prowadzi do prawidłowych decyzji dotyczących wejścia lub wyjścia z inwestycji.

\section{BIBLIOGRAFIA}

Dróżdż S. i in., 2008, Log-periodic self-similarity: An emerging financial law?, Elsevier Science, Kraków, http://arxiv.org/pdf/cond-mat/0209591v2.pdf [data dostępu: 06.06.2012].

Dróżdż S., Bartolozzi M. i in., 2008, Self-Similar Log-Periodic Structures in Western Stock Markets from 2000, APS, Kraków, http://arxiv.org/pdf/cond-mat/0501513v4.pdf [data dostępu: 06.06.2012].

Dróżd ż S., Grumme r F., Ruf F., S peth J., 2005, Prediction oriented variant of financial log-periodicity and speculating about the stock market development until 2010, Polish Academy of Sciences, Kraków.

D różd ż S., O ś w i ę c i mk a P., 2009, World stock market: More sizeable trend reversal likely in February/March 2010, Institute of Nuclear Physics, Kraków.

Dróżdż S., Oświęc i mka P., Kwapi én J., 2008, Criticality Characteristics of Current Oil Price Dynamics, „Acta Physica Polonica A”, vol. 114, Kraków.

Dróżdż S., Ruf F. i in., 2008, Imprints of log-periodic sel-similarity in the stock market, Institute of Nuclear Physics, Kraków.

Gna cińs ki P., M a kow i e D., 2004, Another type of log-periodic oscillations on Polish stock market, „Physica A”, nr 344.

Ide K., S ornette D., 2002, Oscillatory finite-time singularieties in finance, population and rupture, „Physica A”, nr 307.

Oświęci mk a P., Dróżdż S., Kw apień J., Górski A. Z., 2009, Fractals, log-periodicity, financial crashes, „Acta Psysica Polonica A”, Rzeszów.

S o r n e t t e D., 2003, Why stock markets crash, Princeton University Press, Princeton.

S ornette D., J oh an sen A., 2001, Significane of log-periodic precursors to financial crashes, „Quantitative Finance", no. 1.

Sornette D., Zhou W. X., 2002, The US 2000-2002 Market Descent: How much longer and deeper?, Los Angeles.

V and ew alle N. i in., 1999, Visualizing the log-periodic pattern before crashes, „The European Physical Journal B", Liege.

Vandewalle N., Ausloos M., Bouveroux Ph., Minguet A., 1998, How the financial crash of October 1997 could have been predicted, „The European Physisca 1 Journal B”, no. 2.

\section{THE APPLICATION OF LOG-PERIODICITY THEORY IN FORECASTING FINANCIAL CRASHES}

The main purpose of this article is to apply the newest forecast methods of financial crashes based on fractal analysis. The article includes short review of log-periodicity formulas and the research which shows the forecasting efficiency of these formulas referring to extremely different 
(in the size, development etc.) financial markets. Considerations refer to following problem: share price trajectories contain certain log-periodicity patterns which indicate the lack of share market efficiency. This problem is also induced by specific investor's behavior. This behavior in combination with speculators activities are the main reasons of creating bubbles and financial crashes.

Key words: financial market efficiency, technical analysis, log-periodicity theory, financial crash, fractal analysis. 